\title{
POULTRY SALMONELLA SPECIFIC BACTERIOPHAGE ISOLATION AND CHARACTERIZATION
}

\author{
M. T. Rahaman, M. Rahman*, M. B. Rahman, M. F. R. Khan, M. L. Hossen, M. S. Parvej and S. Ahmed
}

Department of Microbiology and Hygiene, Bangladesh Agricultural University, Mymensingh, Bangladesh

\begin{abstract}
Bacteriophage named as SAL-PG (Salmonella bacteriophage), specific to Salmonella pullorum and Salmonella gallinarum was isolated by an enrichment method directly from waste water near to poultry farm. For the isolation of phage $4.5 \mathrm{ml}$ water sample, $0.5 \mathrm{ml}$ of $10 \mathrm{X}$ Nutrient Broth and $0.5 \mathrm{ml}$ of log phage bacteria were mixed well and incubated at $37^{0} \mathrm{C}$ for overnight followed by centrifugation at 10,000 rpm for 10 minutes. The presence of bacteriophage was observed by spot test over the bacterial lawn of and plaque assay. The host range of the isolated bacteriophage was determined by spot test using 12 different bacterial isolates. The phages were found to infect Salmonella pullorum, Salmonella gallinarum and Salmonella typhimurium and produced clear plaque on these Salmonella serovars. The bacteriophage was able to survive in wide range of $\mathrm{pH}$ between 2 to 9 and resistant at $60^{\circ} \mathrm{C}$ for 1 hour. More than 50\% phages were readily adsorbed to the host bacteria. The restriction enzyme analysis showed that the phage DNA possess restriction site for TaqaI, HindIII and BstYI; but no restriction site for XhoI and BstEII as these two enzymes failed to digest the phage DNA. The characterizations of the bacteriophage would be helpful in establishing a basis for adopting the application of the most effective bacteriophage treatment to control these poultry bacteria.
\end{abstract}

Key words: Avian salmonella, Bacteriophage SAL-PG, Phage therapy

\section{INTRODUCTION}

Salmonellosis is one of the main infections affecting commercial poultry, responsible for losses to poultry production, besides their public health importance (Berchieri et al., 2001). Salmonella infect poultry and may lead to pullorum disease (Salmonella pullorum); fowl typhoid (Salmonella gallinarum) and fowl paratyphoid caused by any other salmonella species (Berchieri et al., 2000).

Bacteriophages are bacterial viruses that are the most abundant life form on the planet, widely distributed in soil, hot springs, deep seas, and water (Hendrix, 2003). Phages are currently suggested as possible alternatives to antibiotics for the treatment of bacterial diseases in humans and animals and widely explored to minimize the pathogen loads in food products of animal and plant origin. Bacteriophages are self-replicating and release from bacteria by lysis of the host bacteria (Connerton and Connerton, 2005). Phages have a wide variety of advantages over antibiotics or other chemical agents as they target only the pathogens of interest, not affecting normal microflora. There is no adverse effect on human or animal immune system.

Bacteriophages have been successfully used to treat bacterial diseases in animals (Smith and Huggins, 1983; Atterbury et al., 2003; Huff et al., 2005; Tanji et al., 2005). These instances demonstrated that phage therapy can be as efficient as antibiotics in treating bacterial infections.

Infection with bacteria of the genus Salmonella are responsible for major problems in poultry farming including in several countries Bangladesh (Kamaruddin and Giasuddin, 2003). The emergence of Salmonella strains that are multidrug resistant are increasing day by day. To control bacterial infections, antibiotics are randomly used in poultry farm without proper justification for the treatment; this has resulted in the development of antibiotic resistance in many strains, making the treatment difficult. Antibiotic resistance in bacterial pathogens is a global crisis now; on the other hand, discovery of new drug or antibiotics are expensive and time consuming. All these factors have emphasized the need to develop new strategies for treating multidrug resistant bacterial infections (Preisner et al., 2010). In view of the above situation the present study was undertaken for isolation and characterization of bacteriophage which infect poultry salmonella.

\section{MATERIALS AND METHODS}

Sample collection and enrichment

To isolate the bacteriophage specific to poultry Salmonella the river, drainage \& sewage water samples

*Corresponding e-mail address: marzia_micro@yahoo.com

Copyright (c) 2014 Bangladesh Society for Veterinary Medicine

All rights reserved 0297/2014 


\section{T. Rahaman and others}

suspected to contain bacteriophage were collected which was near to Bangladesh Agricultural University poultry farm and experimental Animal House of Dept. of Microbiology and Hygiene, BAU, Mymensingh and transferred to the laboratory of the Department of Microbiology and Hygiene, BAU, Mymensingh using proper sample transportation techniques; during July to December 2013.

To increase the number of bacteriophage possibly present in the collected samples $4.5 \mathrm{ml}$ of water samples, 0.5 $\mathrm{ml}$ of $10 \mathrm{X}$ nutrient broth (Himedia, India) and $0.5 \mathrm{ml}$ of $\log$ phase bacteria $\left(\mathrm{OD}_{-600}=1\right)$ were mixed well followed by overnight incubation at $37^{\circ} \mathrm{C}$. The samples were then centrifuged at $10,000 \mathrm{rpm}$ for 10 minutes at $4^{0} \mathrm{C}$, decanted; supernatants were collected and filtered by $0.45 \mu \mathrm{M}$ cellulose acetate syringe filter into a sterile glass or polypropylene vials.

Further the filtrates were used to detect the phage. The filtered lysates were treated with chloroform (to a $2.5 \%$ final concentration), stored at $5^{0} \mathrm{C}$, and titered by double-agar-layer plaque assay according to the method of Adams MH (1959).

\section{Detection of bacteriophages Spot test and plaque assay}

On nutrient agar plate, $1 \mathrm{ml}$ of cultured bacteria was spread, the excess fluid was removed and the plates were kept at room temperature for air dry. Then $10 \mu \mathrm{l}$ of filtrated supernatant was spotted on the agar forcefully and allowed to dry. The agar plates were incubated at $37^{\circ} \mathrm{C}$ for overnight for the detection of lytic spot over the bacterial lawn on to the agar plate. After detection of bacteriophage by spot test plaque assay was performed to isolate the bacteriophage using exponential growth phase Salmonella host culture. In brief, $100 \mu 1$ of cultured bacteria and $100 \mu \mathrm{l}$ of filtrated supernatant of phage lysate were taken in a sterile ependrof tube which was then mixed with $2.5 \mathrm{ml}$ of soft agar ( $0.6 \%$ nutrient agar). Test suspension was then poured onto a nutrient agar plate, spread uniformly through the plate and kept at room temperature (RT) for 10 minutes to solidify. Soft agar overlays were allowed to harden at room temperature and then plates were inverted and incubated overnight at $37 \mathrm{C}$. Next day the ability of plaque production by bacteriophage were detected. The numbers of plaques were counted as plaque forming unit (PFU).

\section{Purification of plaque}

A plaque was collected with the help of a micropipette tip and mixed with $300 \mu 1$ of distilled water and incubated for $30 \mathrm{~min}$ followed by centrifugation at 5,000 rpm for $10 \mathrm{~min}$ which was then subjected to plaque assay. This process was repeated for three times to obtain homogenous plaques.

\section{Determination of host range}

Nine isolates of Salmonella spp, \& one isolate of enterotoxigenic E. coli, Pasteurella multocida and Haemophilus paragallinarum each were used in this study to determine the host range of the isolated phages. The bacterial isolates were obtained from the repository of Dept. of Microbiology and Hygiene, Bangladesh Agricultural University. Host range of bacteriophages was determined by spotting $10 \mu \mathrm{l}$ of bacteriophage preparation $\left(\sim 10^{10} \mathrm{pfu} / \mathrm{ml}\right)$ on cultures of each bacterial isolates. The plates were observed for positive result by observing the appearance of lytic clear zones after incubation at $37^{\circ} \mathrm{C}$ for 18 to $36 \mathrm{~h}$.

\section{Efficiency of plating (EOP)}

To determine the efficiency of plating (EOP) means the ability of plaque production on each susceptible bacterial strain, the phage stock was subjected to plaque assay using all of nine Salmonella isolates. The numbers of plaques were counted. Higher number of plaque produced on bacteria was considered as the higher efficiency of plating (EOP).

\section{Heat and $p^{\mathrm{H}}$ susceptibility tests}

The heat susceptibility of phage was measured by treating the phage stock at $50^{\circ} \mathrm{C}, 60^{\circ} \mathrm{C}, 70^{\circ} \mathrm{C}$ and $80^{\circ} \mathrm{C}$ for 1 hour. For $\mathrm{p}^{\mathrm{H}}$ stability, samples of bacteriophages were mixed in a series of tubes containing nutrient broth of different $\mathrm{p}^{\mathrm{H}}$ ranging between 2 to 9 (adjusted using $\mathrm{NaOH}$ or $\mathrm{HCl}$ ) and incubated at $37^{\circ} \mathrm{C}$ for 30 min. Bacteriophage titers were determined using the double-layer agar plate method or plaque assay method. 


\section{Determination of adsorption rate}

To determine the adsorption rate, Salmonella bacterial cells were grown in nutrient broth to exponential phase, then infected with the phage SAL-PG at Multiplicity of Infection (MOI) 0.0001, and incubated at room temperature. Samples were taken at different time intervals such as 5, 10, 15, 20, 25, 30, 35 and 40 min. and centrifuged. The supernatants were used for plaque assays to determine the titers of non adsorbed phages (Hadas et al., 1997). This experiment was repeated three times independently.

\section{Effects of Bacteriophage on Salmonella}

One test tube was filled with $4.5 \mathrm{ml}$ nutrient broth, $500 \mu 1$ host bacterial culture and $100 \mu \mathrm{l}$ of bacteriophage and another test tube was also filled with similar components where $100 \mu \mathrm{L}$ of PBS was added instead of bacteriophage which was kept as untreated control followed by incubation at $37^{\circ} \mathrm{C}$ overnight. The killing activity of bacteriophage was recorded by determination of $\mathrm{OD}_{600}$ (optical density) value of both phage treated and untreated samples.

\section{DNA purification}

The DNA of the isolated phage was extracted and purified using Invisorb® Spin Virus DNA Mini Kit following the instruction provided by the manufacturer.

\section{Restriction Endonuclease (RE) analysis}

Purified DNAs were digested individually with TaqaI, XhoI, Hind III, BstYI and BstEII.

\section{RESULTS}

\section{Isolation and purification of bacteriophage}

Six Salmonella bacteriophages were isolated by enrichment method, one of which exhibited wide lytic efficiency against different isolates of Salmonella, whereas others had a narrow host range. According to the degree of transparency of plaques and the host range, we selected one of the isolated bacteriophages, named SAL-PG for further study, propagating with specific Salmonella gallinarum and Salmonella pullorum host strain. In the plaque assay, the SAL-PG formed round and big lytic zones. The titers of bacteriophage SAL-PG against their host bacteria was $1.47 \times 10^{10} \mathrm{pfu} / \mathrm{ml}$ (Fig. 1).
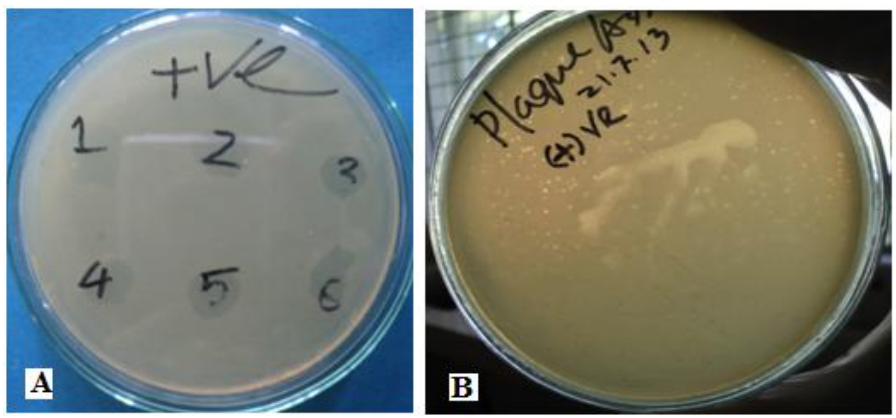

Fig. 1. Lysis of Salmonella enteric serovar gallinarum by isolated phage SAL-PG on spot test method (A) and tiny lytic areas (plaque formation) on Salmonella enteric serovar gallinarum by isolated phage SAL-PG on plaque assay method (B).

\section{Host Ranges}

The host ranges of the bacteriophage were determined using several Salmonella enterica biovar gallinarum and pullorum and E. coli, Pasteurella multocida, Haemophilus paragallinarum. The bacteriophage showed wide host range among Salmonella serovar. The SAL-PG was found to infect both S. gallinarum and S. pullorum. The results indicated that SAL-PG was able to lyse 7 out of the 9 Salmonella isolates (77.77\%). The bacteriophage did not produce lytic plaques on E. coli, P. multocida or Haemophilus paragallinarum. 


\section{T. Rahaman and others}

Table 1. Host range of bacteriophage SAL-PG and Efficiency of plating (EOP)

\begin{tabular}{|lllll|}
\hline $\begin{array}{l}\text { No. of } \\
\text { isolates }\end{array}$ & Bacterial host & Spot test ${ }^{\mathrm{a}}$ & $\begin{array}{l}\text { Plaque production } \\
\text { ability }\end{array}$ & $\begin{array}{l}\text { Total no. of plaque (pfu/ml) / } \\
\text { Efficiency of plating(EOP) }\end{array}$ \\
\hline 01 & Salmonella gallinarum & - & - & - \\
02 & Salmonella gallinarum & ++ & + & $1.47 \times 10^{10}$ \\
03 & Salmonella gallinarum & + & + & $1.5 \times 10^{9}$ \\
04 & Salmonella pullorum & + & + & $1.9 \times 10^{9}$ \\
05 & Salmonella typhimurium & + & + & $1.2 \times 10^{10}$ \\
06 & Salmonella typhimurium & - & - & - \\
07 & Salmonella pullorum & + & + & $1.96 \times 10^{9}$ \\
08 & Salmonella pullorum & + & + & $2.6 \times 10^{9}$ \\
09 & Salmonella gallinarum & + & + & - \\
10 & Escherichia coli & - & - & - \\
11 & Pasteurella multocida & - & - & \\
12 & Haemophilus & paragallinarum & - & -
\end{tabular}

a $++=$ large clear lysis, $+=$ small clear lysis, $-=$ no lysis of plating

\section{Efficiency of plating (EOP)}

The plaque formation ability of bacteriophage SAL-PG against seven out of nine isolates was determined. The number of plaques produced on susceptible bacteria was varied from one isolate to another (Table 1).

\section{Effects of temperature}

Phage titers were decreased when exposed to $50^{\circ} \mathrm{C}$ and $60^{\circ} \mathrm{C}$. The numbers of plaques were $1.53 \times 10^{8} \mathrm{pfu} / \mathrm{ml}$ and $1.43 \times 10^{8} \mathrm{pfu} / \mathrm{ml}$ at $50^{\circ} \mathrm{C}$ and $60^{\circ} \mathrm{C}$ respectively compare to the untreated control. However, no phage was detected at $70^{\circ} \mathrm{C}$ and $80^{\circ} \mathrm{C}$ (Fig. 2) i.e the phages are unstable at $70^{\circ} \mathrm{C}$ and $80^{\circ} \mathrm{C}$ when treated for 1 hour.

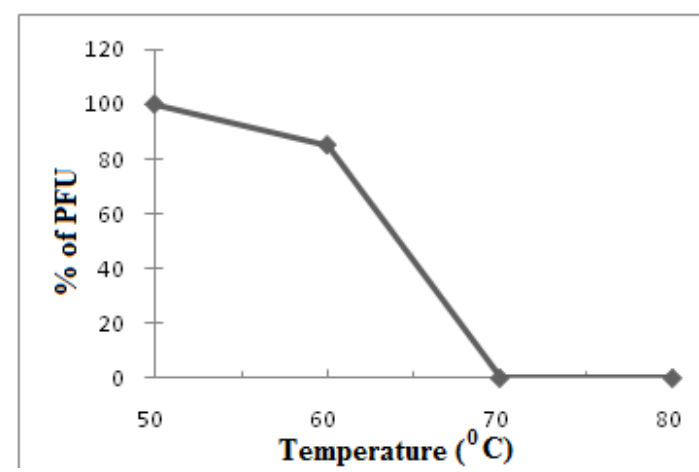

\section{Effects of $\mathbf{p}^{\mathrm{H}}$}

Fig. 2. Heat stability test of SAL-PG $\left(\mathrm{X}=\%\right.$ PFU. $\mathrm{Y}=$ temperature $\left.{ }^{\circ} \mathrm{C}\right)$

The phage lysate was subjected to treatment at various $\mathrm{pH}$ (2 to 9), According to the $\mathrm{p}^{\mathrm{H}}$ susceptibility test, the phage titres were $20 \%$ and $60 \%$ decreased when treated at $\mathrm{p}^{\mathrm{H}} 2$ and 3 respectively, whereas in $\mathrm{p}^{\mathrm{H}} 4$ to 9 the phage titres were found similar to the untreated control, that indicates the ability of the isolated phage to survive and remain active at wide range of $\mathrm{p}^{\mathrm{H}}$ (Fig. 3 ). 


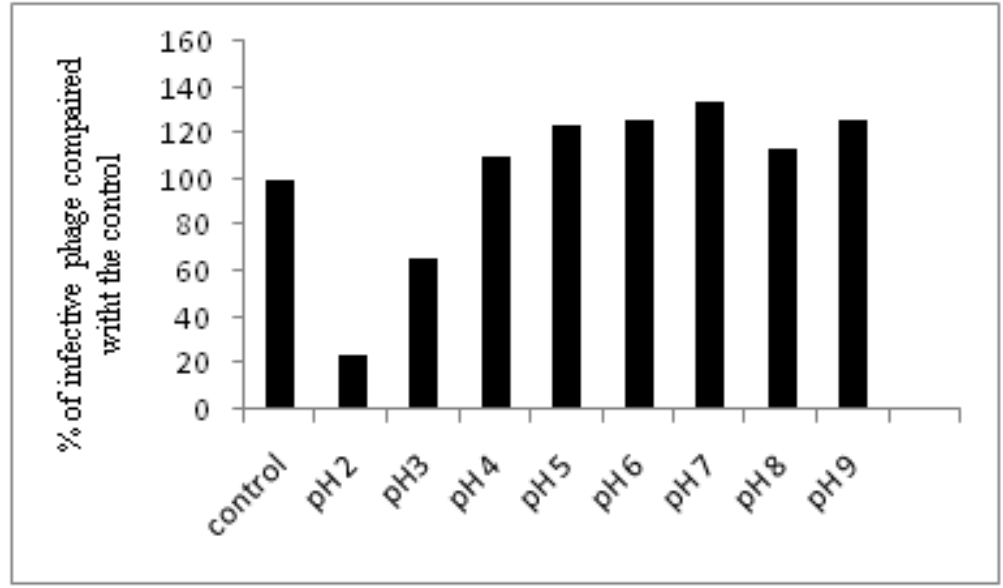

Fig. 3. pH stability of phage SAL-PG

\section{Effects of Bacteriophage on growth of Salmonella}

After overnight incubation of bacteriophage and susceptible host bacteria, the OD value was decreased $\left(\mathrm{OD}_{600^{-}}\right.$ $=0.63)$ in phage treated samples comparing the untreated bacterial culture $\left(\mathrm{OD}_{600}=1.212\right)$ indicating the number of bacteria were decreased due to killing of bacteria by bacteriophage SAL-PG. In this study the phage untreated test tube showed more cloudiness compared to the bacteriophage treated one.

\section{Determination of adsorption rate}

Adsorption studies were performed to identify the adsorption rate of phage SAL-PG on host bacteria Salmonella gallinarum.

According to the phage adsorption assay, >95\% of SAL-PG could adsorb to a host bacteria within 15 min. After 5 minutes more than $50 \%$ phages were adsorbed to their host bacteria indicating that the phages were readily adsorbed to the host (Fig. 4).

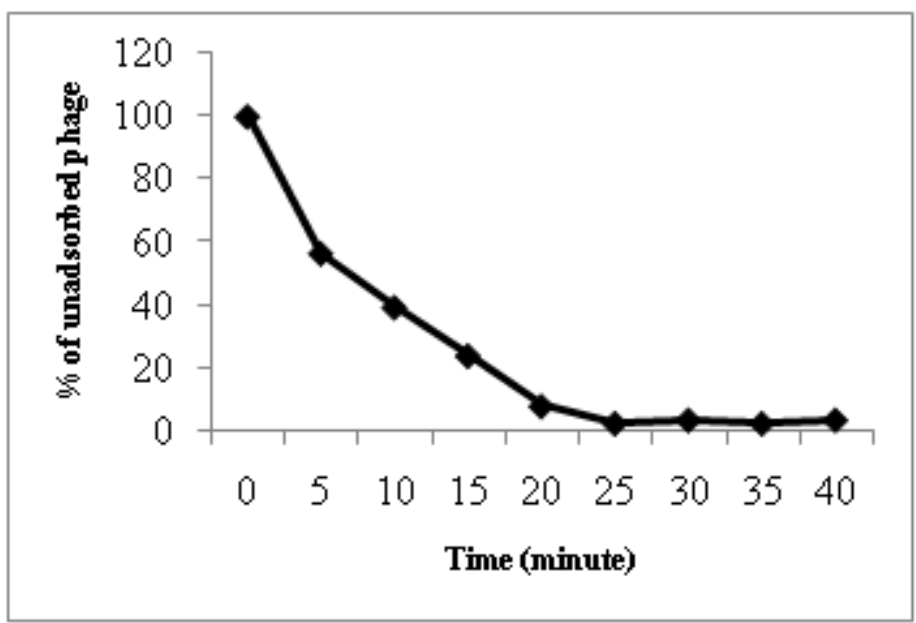

Fig. 4. Adsorption assay of phage SAL-PG 


\section{T. Rahaman and others}

\section{Restriction enzyme analysis}

The genomic DNA of phage SAL-PG was digested with TaqaI, BstYI, HindIII, XhoI and BstEII. Among them TaqaI, HindIII and BstYI were able to cut the genomic DNA and yielded 4-7 bands i.e. the phage genome possessing restriction site for these three enzymes (Fig. 5).

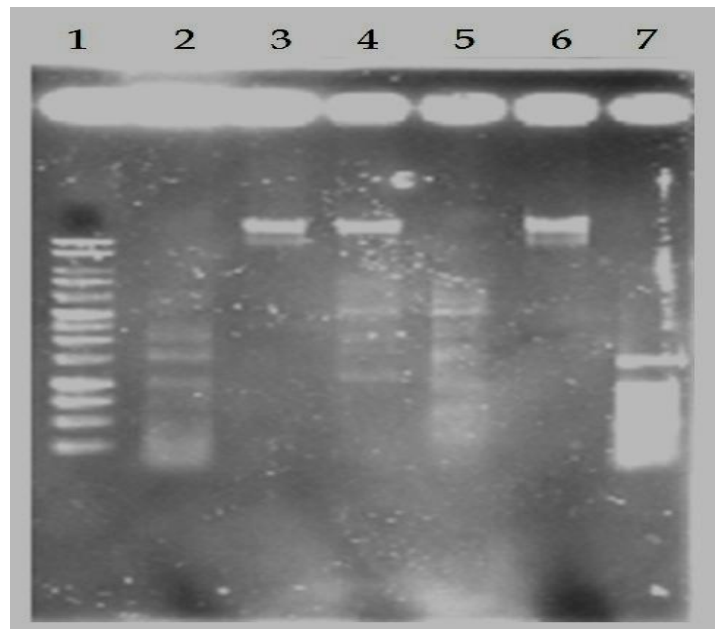

Fig. 5. Restriction enzyme analysis of phage genomic DNA. Lane 1: $1 \mathrm{~kb}$ ladder, lane 2, 3, 4, 5, 6 and 7: Taqa1, XhoI, HindIII, BstYI, BstEII digested phage DNA and 100bp ladder respectively.

\section{DISCUSSION}

Phages are the viruses that eat or kill bacteria for their survival. In the present study phage SAL-PG was isolated from sewage effluent around poultry installation and was found to kill the S. gallinarum, S. pullorum and $S$. typhimurium. It has been observed that for almost all the bacteria exist in the environment, a phage corresponding to that bacterium is also present there and so phages offer potential for targeted biological control of bacterial pathogens in human, animal and plant diseases (Lederberg, 1996; Schuch et al., 2002). Isolation of phages from the environment in which a suspected bacterium resides has been a common finding against various bacteria (Xie et al., 2005; Salamaf et al., 1989). In this work, bacteriophages of S. gallinarum and $S$. pullorum from sewage were isolated and characterized. Bacteriophages that killed Salmonella have been isolated from sewage water and poultry litter has been reported earlier (Berchieri et al., 1991; Sklar and Joerger, 2001), which demonstrates their natural occurrence in the environment. Presence of lytic phages against an organism is an indicator of presence of the organism itself in the environment.

Some authors used bacteriophages against $S$. gallinarum and S. pullorum as biocontrol agent both in vivo and in vitro as well as for the detection of bacteria (Snyder, 2012). To the best of our knowledge, this is the first attempt on the isolation of bacteriophages against $S$. gallinarum, S. pullorum and S. typhimurium in Bangladesh.

Determination of the lytic range of the phage is an important step that helps in selection of phage candidate / candidates for a specific purpose. Phages having lytic activity against a wide range of biotypes of the organism are preferred when they are intended to be used for therapeutic application. Phage designated as SAP-PG showed lytic activity against all three Salmonella strains was selected for further investigations.

The phage SAL-PG showed wide host host range against Salmonella, which is helpful to kill or lyse almost all Salmonella infecting poultry. Resistance to heat and $\mathrm{pH}$ were investigated. Phage SAL-PG showed resistance at low $\mathrm{pH}(\mathrm{pH}-2)$ and high temperature. This would have allowed them to survive at low $\mathrm{pH}$ during the digestive process and would have made their use to control Salmonella Pullorum more efficacious which is similar with the findings of (Bao et al., 2011). In vitro the efficacy of phage SAL-PG was also studied. After treatment of 
planktonic culture of Salmonella gallinarum the OD value was decreased to 0.65 in phage treated sample compare to phage untreated control one (1.212) which showed the reduction of number of bacteria. This property may be helpful to use the phage SAL-PG as therapeutic agent in vivo study in chicks to control poultry Salmonella which is similar with other findings (Lim et al., 2011)

\section{CONCLUSION}

A total of 2 bacteriophages were successfully isolated from expected samples. Among the isolated phage, SALPG showed wide spectrum of lytic activities against Salmonella organism. The isolated bacteriophage SAL-PG produced a clear zone of lysis when incubated with Salmonella spp and has broad host range infecting seven of nine salmonella isolates $(77.7 \%)$ tested. The efficiency of plating (EOP) varied from isolate to isolate. Initial numbers of phage were decreased when phage lysate was exposed to $50^{\circ} \mathrm{C}$ and $60^{\circ} \mathrm{C}$. The SAL-PG was found to be viable in $\mathrm{p}^{\mathrm{H}}$ ranging from 2to 9 . The restriction enzyme analysis of phage DNA revealed that the phage genome possess restriction site for TaqaI, HindIII and BstYI. The OD value was decreased (from 1.212 to 0.63 ) in phage treated bacterial culture compare to untreated one.

\section{ACKNOWLEDGEMENTS}

The authors are gratefully acknowledging BAURES (Bangladesh Agricultural University Research System) for funding the research work.

\section{REFERENCES}

1. Adams MH (1959). Bacteriophages. Interscience, New York.

2. Atterbury RJ, Connerton PL, Dodd CE, Rees CE and Connerton IF (2003). Application of host-specific bacteriophages to the surface of chicken skin leads to a reduction in recovery of Campylobacter jejuni. Applied and Environmental Microbiology 69: 6302-6306.

3. Bao H , Zhang H and Wang R (2011). Isolation and characterization of bacteriophages of Salmonella enterica serovar Pullorum. Poultry Science 90: 2370-2377.

4. Berchieri JA (2000). Salmoneloses aviarias In: Berchieri Jr A, Macari M, Doencas das aves. Facta, Campinas, 185-196.

5. Berchieri JA, Lovell MA and Barrow PA (1991). The activity in the chicken alimentary tract of bacteriophages lytic for Salmonella typhimurium. Research in Microbiology 142: 541-549.

6. Berchieri JA, Murphy CK, Marston K and Barrow PA (2001). Observations on the persistence and vertical transmission of Salmonella enteric serovars Pullorum and Gallinarum in chickens: effect of bacterial and host genetic background. Avian Pathology 30: 229-239.

7. Connerton PL and Connerton IF (2005). Microbial treatments to reduce pathogens in poultry meat. Food Safety Control in the Poultry Industry. G Mead, ed. Woodhead Publishing Ltd. Cambridge, UK, p. 414-427.

8. Hadas H, Einav M, Fishov I and Zaritsky A (1997). Bacteriophage T4 development depends on the physiology of its host Escherichia coli. Microbiology 143: 179-185.

9. Hendrix RW (2003). Bacteriophage Genomics. Current Opinion in Microbiology 6(5): 506-511.

10. Huff WE, Huff GR, Rath NC, Balog JM and Donoghue AM (2005). Alternatives to antibiotics: Utilization of bacteriophage to treat colibacillosis and prevent foodborne pathogens. Poultry Science 84: 655-659.

11. Kamaruddin KM and Giasuddin M (2003). Poultry diseases and its diagnostic facilities. Growth of poultry industry in Bangladesh with poverty alleviation and employment opportunity. In proceedings of $3^{\text {rd }}$ international poultry show and seminar, from February 28 to March 2, 2003, held in Bangladesh China Friendship Conference Centre (BCFCC), Sher-e-Banglan Nagar, Dhaka, Bangladesh, p. 9-15.

12. Lederberg J (1996). Smaller fleas ad infinitum: Therapeutic bacteriophage redux. Proceedings of the National Academy of Sciences 93: 3167-3168.

13. Lim TH, Lee DH, Lee YN, Park JK, Youn HN and Kim MS (2011). Efficacy of bacteriophage therapy on horizontal transmission of Salmonella gallinarum on commercial layer chickens. Avian Diseases 55: 435-438.

14. Preisner O, Guiomar R, Machado J, Menezes JC and Lopes JA (2010). Application of Fourier transform infrared spectroscopy and chemometrics for differentiation of Salmonella enterica serovar Enteridis phage types. Applied and Environmental Microbiology 76 (11): 3538-3544.

15. Salamaf S, Bolton J and Hutchinso DN (1989). Improved method for the isolation of Campylobacter jejuni and Campylobacter coli bacteriophages. Letters in Applied Microbiology 8. 


\section{T. Rahaman and others}

16. Schuch R, Nelson D and Fischetti VA (2002). A bacteriolytic agent that detects and kills Bacillus anthracis Nature 418: 884-889.

17. Sklar IB and Joerger RD (2001). Attempts to utilize bacteriophagen to combat Salmonella enterica serovar Enteritidis infection in chickens. Journal of Food Safety 21: 15-29.

18. Smith HW and Huggins MB (1983). Effectiveness of phages in treating experimental Escherichia coli diarrhoea in calves, piglets and lambs. Journal of general microbiology 129: 2659-2675.

19. Snyder AB (2012). Isolation and characterization of bacteriophage for the control of enterohemorrhagic Escherichia coli on fresh produce.Thesis, Undergraduate Program in Arts and Sciences, The Ohio State University.

20. Tanji Y, Shimada T, Fukudomi H, Nakai Y and Unno H (2005). Therapeutic use of phage cocktail for controlling Escherichia coli O157: $\mathrm{H} 7$ in gastrointestinal tract of mice. Journal of Bioscience and Bioengineering 100: 280287.

21. Xie H, Zhuang X, Kong J, Ma G and Zhang H (2005). Bacteriophage Esc-A is an efficient therapy for Escherichia coli 3-1 caused diarrhea in chickens. The Journal of General and Applied Microbiology 51: 159-163. 